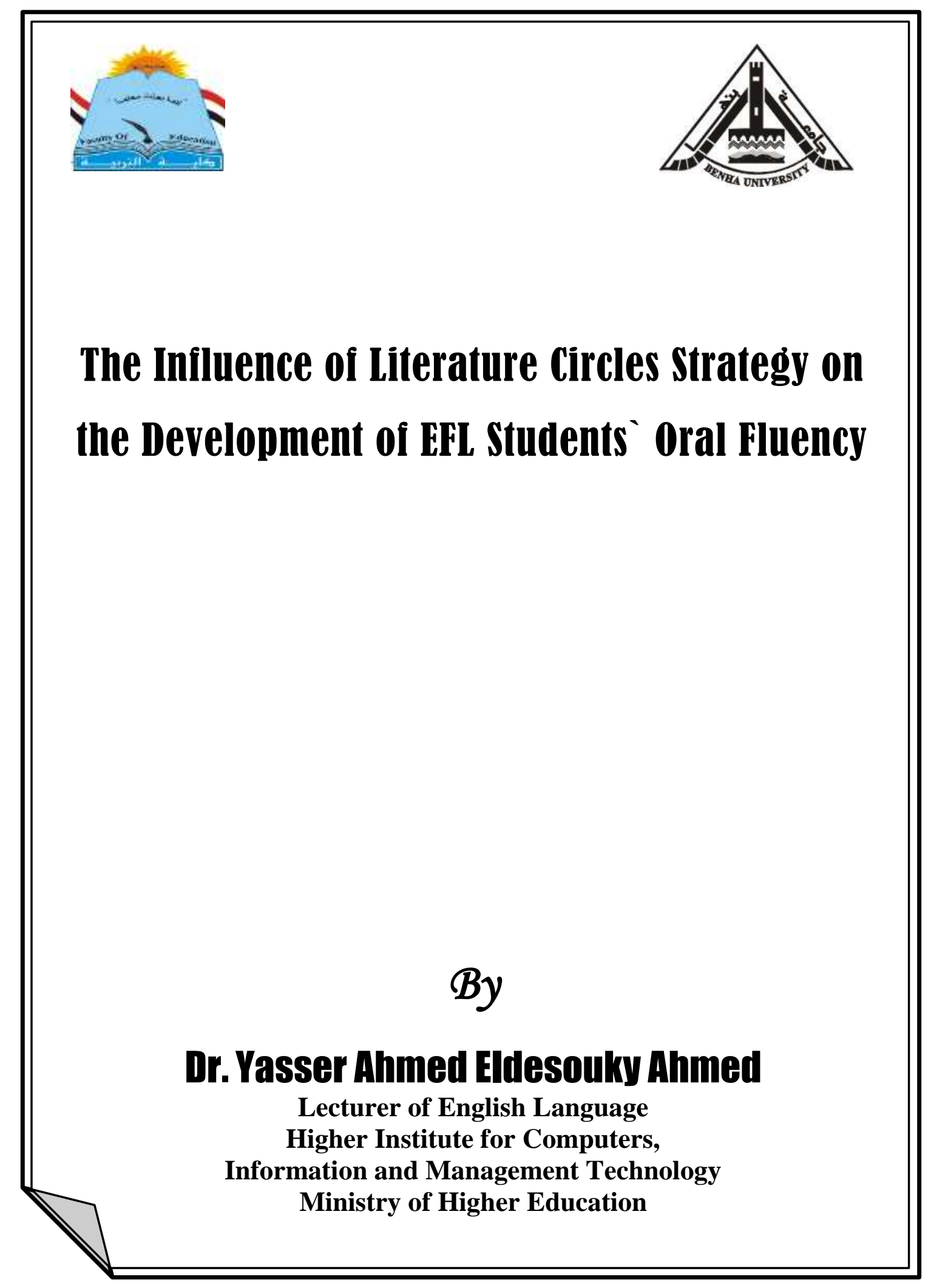




\title{
The Influence of Literature circles Strategy on the Development of EFL Students` Oral Fluency
}

\author{
By \\ Dr. Yasser Ahmed Eldesouky Ahmed \\ Lecturer of English Language \\ Higher Institute for Computers, \\ Information and Management Technology \\ Ministry of Higher Education
}

\section{Ahstract}

The study investigated the influence of literature circles strategy on the development of EFL students` oral fluency. Two intact classes $(\mathrm{N}=100)$ were chosen randomly during the first semester of the school year 2018-2019 from EFL third year preparatory students, Gharbia Governorate. The participants were assigned into an experimental group $(\mathrm{N}=50)$ and a control group $(\mathrm{N}=50)$. The students of the experimental group received instruction based on literature circles, whereas the students of the control group received regular instruction. The instruments of the study, prepared by the researcher, were a prepost oral fluency test and an oral fluency scoring rubric. The two groups were tested before and after conducting the experimentation using the instruments. Data were analyzed using SPSS. The T- test for independent and paired samples was used in the study. Results indicated the positive influence of literature circles strategy on the development of EFL third year preparatory students` oral fluency. In the light of these results, implications, recommendations, suggestions for future research and conclusions were provided.

Keywords: Literature Circles, Oral Fluency

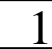




\section{Introduction}

EFL teachers have difficulties in selecting an effective strategy that helps and encourages their EFL students to speak fluently inside and outside the EFL classroom. An effective strategy should enable students develop their foreign language skills without total guidance of EFL teacher. Some strategies are useful and effective, but do not challenge and encourage students to speak EFL fluently. Teachers should bring something new to their students that challenges, encourages, motivates and engages them to speak fluently. How can EFL teachers provide a strategy that challenges and motivates their students to speak fluently without guidance of the teacher?

There are several strategies for enabling EFL students develop and enhance their oral fluency performance. Among the suggested strategies is the literature circle. It is somewhat like a student book club in the classroom that has drawn a great deal of care and attention in recent years. Many EFL teachers can utilize the strategy and use it consistently in their EFL classrooms for its efficacy in developing EFL language skills (Daniels, 2002) .

Literature circles (LCs), also known as book clubs, are small, heterogeneous, peer-led discussion groups in which EFL students have chosen to read, discuss and negotiate the same text, story, book, chapter or article. These groups should be directed by students, but at the same time students need a number of tools in order to have interesting, fun and motivating discussion about the selected materials they have been sharing or discussing. LCs were used and implemented at all educational levels and stages (primary, preparatory and university) and were used widely in general education classrooms and popular with many EFL classroom teachers. They are effective in developing EFL foreign language skills (listening, speaking, reading and writing) and many social skills for a broad range of EFL students (Blum, Lipsett,\& Yocom, 2002; Daniels, 2002; Anderson \& Corbett, 2008 \& Certo, Moxley, Reffitt, \& Miller, 2010).

According to Hempel (2005), a literature circle is a group of students gathered to discuss a book or books in depth. The discussion is directed and led by students rather than the teacher. Students are encouraged to talk, discuss and negotiate about the selected materials in their books and compare them to each other, as well as their own personal connections to the selected materials by their own 
experience. This kind of discussion improve and develop the students' foreign language skills while they are discussing and sharing the selected materials.

On the other hand, literature circles are discussion groups of students who have chosen to read the same text where they are provided with prompts called roles. The length and type of text or chapter chosen does not matter as much as the student interest level and that the piece of literature chosen can stimulate meaningful discussion. The literature circles strategy puts the students in the leadership position (Blanton, Wood \& Taylor, 2007 \& Calmer \& Straits, 2014).

Brown (2002) ;Hill, Noe \& King (2003); Lin (2004) \& Daniels (2006) demonstrate that LCs give EFL students the chance to develop connections between the given texts or chapters and personal experiences, take the responsibility and ownership of their own learning, interact with other students in each group and share, discuss and exchange viewpoints and opinions. In addition, LCs help students choose their favorite texts, increase their oral communication skills through discussions that occurred in each group, maximize their thinking skills through free expressions of their opinions and viewpoints, maximize their motivation towards learning EFL through engaging them in meaningful and concrete discussions, give and receive positive and useful feedback from their instructor and from their peers through discussions, integrate all foreign language skills during practicing different roles in LCs and promote respect among students during exchanging thoughts and ideas.

Moreover, Blum et al. (2002); Day et al. (2002); Egle (2002); Casey(2008) \& Carrison et al. (2009) seem to agree up that LCs function as a strategy for helping EFL students generate their own ideas about what they read, accommodate student diversity in inclusive classroom, help EFL students develop their EFL foreign language skills naturally and provide EFL students with conversational structures that assist them with the help of their instructor break away from typical discourse patterns. Moreover, LCs help students think outside of the box, provide students with several opportunities to engage in group discussions, in turn, their foreign language skills can be developed and enhanced, develop the students motivation and attitudes towards learning foreign language, increase 
the students` communication skills and help them become active listeners and risk takers.

Blum et al. (2002); Day et al. (2002); Egle (2002); Casey(2008) $\&$ Carrison et al. (2009) also explain that LCs give students the opportunity to ask questions, negotiate, guess the meaning of unknown words, argue and reflect, help students to get rid of their traditional role and help them to perform new active roles, provide students with opportunities to discuss and engage in conversations on a smaller scale, help students be more skilled in interpreting texts through interacting with their peers, give students more freedom to talk, discuss and share their thoughts and opinions in a comfortable environment, give students the opportunity to participate in makingdecision through selecting texts, group members and roles, help students build community in their classroom through helping them to communicate their opinions and ideas. In turn, they learn new social skills (i.e., problem-solving, treating a conflict, taking turns, making good eye contact, respect differences, supporting their viewpoints, etc.) and develop students discussions as a whole through engaging $100 \%$ of the students in such discussions. In addition, they show that LCs enable and assist EFL instructors hear their students voices during implementing LCs, which in turn, help them recognize their students ideas and thoughts and monitor their learning process.

LCs afford EFL students rich opportunities to develop their foreign language skills as they enable them to learn, communicate and interact with one another in a non- threatening, community- like setting through exchanging ideas, sharing thoughts and negotiating texts. They also allow them develop greater understanding and compassion for others as they examine differences and similarities in the varying insights and experiences of their peers (Lopez-Robertson, 2000; Daniels, 2002 \& Carrison, 2005).

LCs are away to enhance the development of many important skills as they provide a wide array of opportunities for foreign / second language students to practice EFL/ESL. They also offer several opportunities for EFL students to help each other discuss the meaning of the chosen texts and allow them become familiar with ways of discussing literature .They not only develop the EFL students' language skills, but they also develop and foster several thinking skills such as putting themselves into the story, checking and confirming 
facts, making connections with personal experience, looking for patterns, noticing passages and languages, questioning the author and characters, analyzing and savoring the story (Daniels, 2000 \& Carrison, 2005).

\section{The Context of the Problem}

EFL third year preparatory students had good English foundations as they knew grammar structures and vocabulary and they were good at reading and writing, but at the time of speaking EFL, they did not seem to have a good level of oral fluency. This, in turn, made communication unsuccessful as the recipients had problems in understanding their messages since the interaction was interrupted by many filler words, pauses, reformulations and hesitations.

This problem was observed and seen out of many EFL teachers' experience in teaching EFL to preparatory three students in Gharbia Governorate, who were interviewed several times by the researcher. They all agreed that EFL third year preparatory students suffered from such a problem. To confirm the problem, the researcher interviewed a number of EFL supervisors from different educational administrations at Gharbia Governorate and they all seemed to agree that the students really had a problem in their oral fluency .In addition, they mentioned some reasons for this problem, among them," the English test does not have a section for measuring the speaking skill ", " the activities to develop oral fluency are limited "and" it is neglected by decision makers and EFL curriculum developers". Moreover, the researcher held some meetings with a number of EFL third year preparatory students to be aware of their desires to develop their oral fluency. All students expressed their desires and willingness to develop and improve their level of oral fluency and they considered it a must for their future careers.

To document such problem, the researcher piloted a study to a sample of 20 EFL students from third year preparatory students at Said El-Arian Preparatory School, Gharbia Governorate. In the pilot study, an oral fluency test, prepared by the researcher, was given to the 20 students during the first semester of the school year 2018-2019. The researcher evaluated the students` responses according to a rubric and the results showed that the students had a problem in their oral fluency as most of them used inappropriate pauses, had low rate of 
speech, used many filler words, had many hesitations and had many false starts.

In an attempt to overcome and tackle this problem, literature circles strategy is proposed in this study as an effective solution that has been proved to be effective in developing foreign language skills and this can be noticed from the results of the studies that were conducted in this area (i.e., Daniels ,2002 ; Furr ,2004; Reppert ,2004; McElvain ,2005; Hsu \& Liu ,2005 ; Beeghly ,2005; Lin ,2006; Daniels ,2006; Duff \& Maley ,2007; Mark ,2007; Clarke \& Holwadel ,2007; Dasilva Iddings, Risko \& Ramplulla ,2009; Anderson ,2009; Lopez ,2010; Avci \&Yuksel ,2011; Whittaker ,2011; Shelton-Strong ,2012; Azmi ,2013; Clarke ,2013; Calmer \&Straits ,2014; Thomas ,2014 ;Sagan ,2015; Sambolin \& Carroll ,2015 \& Ragland \& Palace ,2017).

\section{Statement of the Problem}

The study problem was that EFL third year preparatory students had low and weak level of oral fluency and the study is an attempt to tackle and solve such problem through answering the following question: "what is the influence of literature circles strategy on the development of EFL third year preparatory students 'oral fluency?" Literature Review

\section{Definition of literature Circles}

"Literature circles" is a strategy in which EFL students meet on a regular and predictable schedule to discuss and respond to a book, a chapter in a book or a text in a chapter that they are all reading or discussing (Daniels, 2002).Cameron et al. (2012) demonstrate that LCs are led and guided mostly by students, while the instructor remains in the background and functions only basic control roles. Roles are usually assigned to students of the LCs to allow them function effectively and help them remain concentrated on the chosen text. For example, students function as: discussion director, literary luminary, illustrator, summarizer and vocabulary enricher (Daniels \& Steineke, 2004). The discussion director's role, for example, could be to prepare some questions about the chosen text and then share such questions with the whole group. The literary luminary stresses important parts of the text for the students of the group for stimulating their thinking and extracting some interesting facts related to the text. The illustrator's role could be to draw pictures related to the text and then share them with the group. Here, the students are asked to 
speculate on their meaning and connect them to their own ideas about the chosen text. The summarizer's role might be to recall what occurred in the reading and prepare a brief for the students of the group. The vocabulary enricher assists the group to find, negotiate and discuss new or unfamiliar words (Daniels \& Steineke, 2004).

\section{Origins and history of Literature Gircles}

According to Daniels (2002) \& Furr (2004), LCs were not invented in the USA, but the first model of them was recorded in 1634 by Anne Hutchinson during her voyage to America. They were probably not invented by Americans, but undoubtedly they were the re-inventors of them and responsible for bringing them to the educational institutions (schools, institutes, universities and academies). One of these re-inventors was Karen Smith, an elementary school teacher in Phoenix, Arizona. She first implemented them in her school in 1982 when some of her fifth grade students found a box that was full of books and they got motivated and interested. They approached Ms. Smith and asked permission to read such books. She agreed as she was assuming that they were for independent reading.

Daniels (2002) \& Furr (2004) also explain that she was surprised with the way her students were organizing themselves, as they formed groups of their choice and assigned themselves texts to discuss and share. They also were regularly meeting to talk, discuss, share and negotiate about their books. She participated in some group discussions with her students and was amazed by the level of their engagement with the books and the complexity of their discussions. She realized that her students had just invented their own literature circles.

In 1994 ,Daniels brought up his innovative idea of literature circles strategy and has persuaded many curriculum reformers (i.e., McMahon \& Raphael, 1997), pedagogists (i.e., Alis, 1994), literacy experts (i.e., Day, 2004) and L1 and L2 language acquisition researchers (i.e., Hsu, 2003, 2004) to enthusiastically embrace such a unique teaching method.

\section{Benefits of Literature Circles}

LCs are very effective as they encourage maximum opportunities for EFL students to be involved and engaged in foreign/second language and they can empower students to become 
instructors and leaders in a collaborative milieu that encourages full participation and interaction. In the everyday classroom structure, it is typically the leaders or students who demonstrate academic strengths in certain subject areas who assume the greatest share of responsibility and attention from peers. In LCs, students are given a unique opportunity to shine to choose their roles and activities that showcase their personal strengths in specific ability areas (Anderson, 2009).

LCs provide EFL students with opportunities to exchange and share their ideas with their members in each group, interact orally, help each other so that they gradually become fluent, promote trust and respect for the opinions of others, think outside the box, increase their understanding of the chosen texts, ask relevant questions, develop their oral and written communication and develop their vocabulary. In addition, LCs enhance their self-confidence, improve their comprehension, encourage them to become active listeners, increase their thinking abilities, improve their self- determination, engage them in discussions and conversations in small sizes that may help them in increasing opportunities for multiple voices to be heard and make the environment of the class room more secure and comfortable (Blum et al., 2002; Lin, 2004; Huang, 2008 ; Carrison,2009\&Whittaker, 2012).

In LCs, EFL students not only develop their foreign language skills, they also learn and acquire new social skills such as participating actively in the group, taking turns, asking questions, making good eye contact, pulling other people in, avoiding interrupting, speaking directly to each other, showing respect for others`ideas, avoiding dominating, learning forward, speaking up when they disagree and disagreeing constructively ,helping others find evidence, explaining what they are thinking and allowing all members of the group to participate (Daniels,2002).

\section{Using LGs Role Sheets with EFL Students}

There are five basic roles for EFL literature circles` groups according to McNair \& Nations (2002); Day (2002); Daniels (2002); Hill,Noe \& King (2003); Daniels (2006); Day \& Kroon(2010);Levy(2011) \& and Whittaker (2011) as follows:

The Group Discussion Leader: whose role is to act as a facilitator in the group and to keep the discussion flowing. He/she is directed to read the story several times to have a very solid grasp of 
the possible themes and the basic plot of the story. He/she opens the discussion with a number of open-ended questions relating to the text and then proceeds to call on other group members to share their results with the group.

The Summarizer: whose role is to provide a summary early in the discussion so that everyone can remember the plot of the story. It is vital to assure that the summarizer provides a brief summary of the plot. He/she should understand that his/her role is not to copy too much from the given text, instead, he/she should retell the text using own words focusing on the most important actions in the text.

The Connector: whose role is to try to find connections between the text and the real world in which he/she lives (i.e., thoughts, feelings or actions) of the characters in the story and family members, friends or classmates.

The Word Master: whose role is to choose some words which he/she believes to be the most important words or very short phrases found in the text of the story. He/she is not required to define new words, but he/she should be encouraged to look for those words that he/she believes are important in the story.

The Passage Person: whose role is to make a very close reading of the text and to look for well-written or key passages in the story. In upper levels, Daniels (2002);Furr (2004), \& Shelton-Strong (2012) believe that the roles performed by the students in literature circles can be extended to the following:

1- Discussion Facilitator: who prepares and develops a number of questions that the students of the group might discuss and negotiate in the text.

2- Passage Finder : who locates a few number of significant passages or texts which are thought of being provoking, funny, interesting, disturbing, motivating or powerful.

3- Illustrator: who draws, sketches or paints in the light of the chosen text.

4- Connector : who locates several significant passages or texts in the story connecting them to real life.

5- Summarizer : who prepares a brief summary of the text that is assigned for that day's meeting. The summary should include the main ideas or events to remember, major characters, symbols or any other significant information in the text. 
6- Vocabulary Enricher (Word Master or Word Wizard) : who records important, unusual or unfamiliar words that are chosen by the students.

7- Travel Tracer : who records where the major shifts in action or location happen in the story, keeps track of shifts in place, time and characters and helps his/her classmates keep track of important shifts in the text.

8- Investigator: who works where background information needs to be existed on any topic related to the text. Historical, geographical, cultural, musical or any other information that may help students connect to the text is often researched and shared with the students of the group.

9- Figurative Language Finder : who determines different kinds of figurative language (i.e., simile, metaphor, personification, hyperbole, idiom, etc.).

\section{Features of Successful EFL Literature Circles}

According to Johnson (2001); Reid (2002); Daniels (2002); Haddon (2003); Kim (2004); Furr (2004) \& Shelton-Strong (2012), the successful EFL LCs should have the following features:

Instructors choose texts appropriate for their students. LCs allow students to participate in real life, meaningful and concrete discussions about the chosen texts/stories that they've read. Thus, it is significant for the instructor to choose appropriate texts that help students improve and promote their oral fluency skills. So, students should be able to deal with texts using a dictionary.

Small temporary groups are formed based on the choice of the students or the instructor's discretion. It is important for the instructor to manage the group dynamics in order to have at least one outgoing student in each small group. the number of students in each group should range from 5-6 students and there should be two stronger students in each group to assure a successful literature circle. So, it is useless when all students of each group are very shy students.

Different groups are dealing with the same text. EFL students should be encouraged to select or participate in selecting the texts for LCs. When students deal with the same text, this allows them to get hooked by the text or the story and then sneak in a mini-lecture to the entire class after the groups have finished their discussions. Thus, LCs 
serve to pique the students' interest and motivation in social and cultural issues.

After the groups finish their discussions, the instructor may then ask the students in each group to produce or create something concrete reflecting their work (i.e., making a poster related to the text, doing a simple plot diagram,etc.) and then they are asked to demonstrate it to the other groups. Because LCs framework allows students to feel that they are having meaningful, concrete, motivating, interesting and real life discussions about the texts of stories, they are always motivated and interested if they are asked to produce something concrete.

Groups come on a regular and predictable schedule to discuss the texts.LCs come or meet on a regular and predictable schedule. LCs require much amount of student training time. Thus, the instructor should be willing to commit to several texts with LCs to have positive results. It is good to put the students into groups of five or six and explain the role sheets one-by-one in simplified English and then allow them to communicate effectively to be sure that each one in each group recognizes and comprehends his/her role. In LCs, students` communication skills can be promoted and improved naturally.

Students use drawn notes to guide their discussions. This is the core and the magic of LCs. The given role sheets prompt each student in each group to deal with the text from different viewpoints and they help break the main skills of the students into their sub-skills. In addition, discussion topics come from the students. It is very essential to help students generate the discussion topics and this enables them to participate in meaningful and real life discussions, even without instructor-directed questions. Moreover, group meetings should be open. So, personal connections, digressions and open-ended questions are desired and wanted. It is essential for EFL students to be encouraged to share their viewpoints about the chosen texts. The instructor should allow natural conversations to occur to achieve communication.

The instructor serves as a facilitator, not a group member or instructor. He/she should allow students carry responsibility for directing the discussions in LCs. For most instructors, it is a very hard role, but if they take notes related to the students ' participation and the selected texts, they can use this information to provide additional 
cultural or historical information to the students in the form of a mini lecture in simplified English. A spirit of playfulness and fun pervades the class .LCs should be motivating, interesting and fun to be away from the traditional atmosphere, in which students feel boredom.

\section{Teacher's Role in Literature Bircles}

The teacher's role in LCs is different from that in the traditional instruction. In LCs, his/her role is to monitor group discussions and help EFL students negotiate, share, communicate and understand the chosen texts, stories, chapters or any selected materials. He/she should care about various obstacles and problems related to language, cultural concepts and idioms. He/she should act as a facilitator who is responsible for motivating and encouraging students talk and interaction. Also, he/she should act as a participant who is responsible for interacting as reader through sharing personal viewpoints, thoughts, connections and questions that based on students` treatment with texts. Moreover, he/she should function as a mediator who encourages students to connect their discussions about the chosen texts to their own life experiences and values. The role of active listener is also an important role that should be performed by teachers in LCs. This role gives students opportunities to be more active and moves away from teacher controlled discussions and leaving the control up to group negotiation (Stein \& Bede, 2004 \& Yedlin, 2004).

During implementing LCs, teachers should demonstrate the questions and discussion behaviors that are appropriate in order to establish a supportive context for sharing and constructing interpretations of literature. Teachers should also encourage students to explore each other`s interpretations and to collaboratively build new understandings of literature through LCs (Daniels, 2002\& Furr, 2004).

Both teachers and students share in the control of the discussion groups. The group discussion begins with the teacher taking an active role as the leader of the group, and then he/she allows students take over and direct the discussion. So, the teacher's presence in LCs influences the dynamics of the group. He/she can change his/her role from leader to member by waiting for students` answers/responses rather than controlling the discussion and giving them opportunities to express their viewpoints and ideas rather than asking questions. 
Teachers can provide different amounts of support and share control with students through trying different variations of the circles in which he/she sometimes present and at other times circulate from group to another or not join the group at all. Instead of being the source of questions or of broad focus for the discussion, students can prepare their own questions or focus (Maloch, 2004; Furr, 2004 \& Daniels, 2006).

The teacher's role in LCs shifts to one of quiet but attentive observation. It is up to the teacher to determine what he or she will be observing and this may alter for each discussion. $\mathrm{He} / \mathrm{she}$ is responsible for observing students` role performance, interaction within groups, language usage, turn taking or procedural concerns. But, it is important for students to understand that they carry the responsibility for managing the interaction and content of their discussions and in this way are led to rely on themselves and each other for language needed or pragmatic issues that may arise, which in turn, allows them be autonomous in improving and developing their foreign/second language skills (Daniels, 2002; Lopez, 2010 \& Shelton-Strong, 2012).

\section{Literature Gircles and Foreign Language Skills}

In LCs, EFL students experience and practice the four language skills (listening, speaking, reading and writing) as students listen to their peers or classmates, speak and discuss their thoughts with their classmates, read the chosen texts or stories and write about the texts and their role sheets. So, there is an integration of the four language skills in LCs (Flynt \& Brozo, 2009 \& Egbert, 2015).

In LCs, students are given several opportunities to practice sharing their own opinions and ideas, listening to a wide range of cultural and linguistic perspectives, negotiating and discussing meaning and thoughts, raising questions of what they want to know, communicating orally through participating in discussions, involving in clarifying meaning and connecting both reading and writing naturally without separation.

LCs help EFL students develop and enhance their foreign language skills that are required when dealing with a text. They support and develop several strategies such as visualizing, connecting, questioning, inferring and analyzing that are important and essential to communication and lively conversation (Daniels \& Steineke, 2004). 
They also demonstrate that EFL learners are called upon to use different skills while preparing for the discussion. While EFL students function their roles, they draw information from the chosen text, pay attention to details to support their ideas, highlight main ideas, communicate effectively and respond critically through making judgments about the characters' intentions and actions and about the ways and the reasons for events that occurred in the story.

LCs help in providing and ensuring a safe classroom environment for EFL students in order to build confidence and feel enabled to take risks while communicating in their second/foreign language. EFL students may feel more comfortable and motivated with their peers and they may be more willing to share their viewpoints and ideas without feeling anxious about making mistakes (Larson, 2008).

In addition, LCs help students feel a sense of ownership and responsibility as they support student motivation and they may have a very strong effect on students achievement in foreign/second language. They encourage each other's efforts and they may increase students` self-confidence and effort (Daniels, 2002; Burner, 2007; Chi, 2008 \& Williams, 2009).

LCs are important and vital through providing a path for EFL students to engage in critical thinking and reflection through collaborative discussions with peers that occur in LCs which are considered a very important factor in reinforcing comprehension and communication skills (Egbert, 2007\& Ketch, 2005).

While working in LCs, students are provided with opportunities for social interaction and communication about issues that are important to them. During the meaningful and concrete oral discussions that are participated in LCs, students have more opportunities to practice oral communication skills that may help develop and improve their oral communication performance. Interactions in LCs may have positive impacts on EFL students language skills as they support and improve greater participation, engagement and involvement for EFL students. Instructors can assign engaging and challenging varied activities that develop students language skills and stimulate their critical thinking (Sawyer,2006; Echevarria; Vogt \& Short, 2008 \& Nagy \& Townsend, 2012). 


\section{Oral Fluency in Foreign Language Development}

Oral fluency in foreign language development $i \quad s$ one of the descriptors of foreign language oral production. Lennon (2000) defines oral fluency as the rapid, smooth, accurate, lucid, and effective translation of thought or communicative intention into language. For De Jong et al. (2015), oral fluency is a speedy and smooth delivery of speech without filled pauses, repetitions, repairs, hesitations, or reformulations. On the hand, Ellis (2009:475) defined fluency as the capacity to use language in real time, to emphasize meanings, possibly drawing on more lexicalized systems.

Housen \& Kuiken (2009) highlight and assert that oral fluency in foreign language development is composed of a number of subdimensions such as speed, breakdown and repair. Housen \& Kuiken (2009) considered oral fluency as a range of measures are available, broadly examining: breakdown fluency, indexed by pausing, repair fluency, indexed by measures such as reformulation, repetition, false starts and replacements and speed fluency with measures such as syllables per minute.

According to Nation \& Newton (2009), the development of learning foreign language implies the development of oral fluency as a sub-skill or a part of speaking skill and fluency is very important in achieving oral communication effectively. On the other hand, oral fluency is one of the most important components of EFL speaking skills, besides accuracy and complexity, and it is an indicator of excellence in foreign/second language, as through it, EFL students can communicate orally effectively, express correctly their ideas and supply a communication need (Goh \& Burns, 2012).

Oral fluency development is essential at all levels and stages of education from the primary education stage to the university level as it is a requirement for all EFL students and it is important to show the relation between fluency and speaking. This relation has been explored by some researchers and authors such as Dotan-Eliaz (2008) who stated that oral fluency is an important sub-skill of speaking and it implies how easy and smoothly a foreign language is expressed and produced without having to stop, pause, think about words, reformulate and hesitate, but speaking is a main skill includes fluency. Dotan-Eliaz (2008) also explained that oral fluency in foreign language does not necessary mean that a student speaks that language 
but he/she shows and declares better communication of ideas conducting to better proficiency.

EFL students are considered fluent when they use EFL smoothly, focus on meaning not form, speak without too many hesitations, use correct patterns automatically in a normal conversational speed, do not make too many or too long pauses, express ideas received and understood by others easily and use a few filler words (Nation \& Newton, 2009 \& Mora \& Valls- Ferrer, 2012).

Oral fluency as a construct can be seen from several perspectives and viewpoints. Koponen \& Riggenback (2000), for example, determined four main viewpoints of oral fluency in foreign language development. The first views oral fluency as smoothness of speech that depends on the temporal, phonetic and acoustical features of speech. The second views fluency as proficiency or as a component of proficiency and this viewpoint is a broader, comprehensive view of fluency as it includes smoothness as only one part of fluency. The third views it as automaticity of psychological processes. The fourth and the last views it as opposed to accuracy. The last view highlights the distinction between accuracy in which students are focused on the language activity itself and fluency in which students are focused on communication.

In the area of investigating the influence of literature circles strategy on the development of foreign language skills, several studies have been conducted and thay all assert and confirm its positive influence on the development of EFL language skills, among them, (Daniels ,2002 ; Furr ,2004; Reppert ,2004; McElvain ,2005; Hsu \& Liu ,2005 ; Beeghly ,2005; Lin ,2006; Daniels ,2006; Duff \& Maley ,2007; Mark ,2007; Clarke \& Holwadel ,2007; Dasilva Iddings, Risko \& Ramplulla ,2009; Anderson ,2009; Lopez ,2010; Avci \&Yuksel ,2011; Whittaker ,2011; Shelton-Strong ,2012; Azmi ,2013; Clarke ,2013; Calmer \&Straits ,2014; Thomas ,2014 ;Sagan ,2015; Sambolin \& Carroll ,2015 \& Ragland \& Palace ,2017). The following is an explanation of some of these studies:

Reppert (2004) investigated the use of literature as materials for helping advanced ESL adult learners develop their oral fluency skills. A number of 15 native Chinese - speaking graduate students associated with Iowa State University participated in the study. Samples of the students` speech were taken before and after a two - 
week treatment period. The participants of the study were randomly assigned to one of three treatment groups. Literature was found effective in developing oral fluency skills.

In her doctoral dissertation, McElvain (2005), from San Francisco University, attempted to investigate the impact of LCs on the development of language skills of a group of at-risk English students. After nine months period, the experimental group students surpassed and outperformed the control group students as there was a statistical difference in means of scores, in favor of the experimental group.

Lin (2006) led 25 fifth graders of Chinese- English bilingual programs to run through several cycles of LCs. The researcher used both quantitative and qualitative methods for collecting data. The positive impacts of LCs in developing EFL language skills of the participants of the study led the researcher to suggest that EFL teachers could adopt students` literature as teaching materials to foster their EFL skills and LCs could be used in different ways to develop and incorporate many different perspectives of learning EFL.

Anderson (2009) implemented online literature circles to increase and enhance online discussion participation and to model effective practice of LCs for purposes of teaching core literature selection that serve highly diverse student populations. MacBeth, Julius Caesar, Romeo and Juliet and Hamlet were chosen as these are the top four Shakespeare plays for high schools in the United States. The discussions took place in LCs over a five-week period with the participants of the study $(\mathrm{N}=26)$ discussing one act of the play per week. The participants chose their roles (summarizer, word master, character sketcher, connector, etc.) and such roles were rotated to provide all group students the experience of each role. Following the five weeks of participation in LCs, the participants were asked to complete a survey related to the quality of such experience (LCs). The majority of students viewed LCs as being valuable and useful.

Dasilva Iddings, Risko \& Ramplulla (2009) attempted to answer the question of "how can EFL teachers help and support their EFL students make meaningful connections to texts through LCs?" To answer this question, the above researchers conducted a study using the classroom micro ethnographic method of research. The 
participants performed several roles in groups that helped them develop their language skills in a natural way using LCs.

Azmi (2013) investigated the impact of implementing LCs in an active learning classroom to develop language skills and soft skills of the university students. The participants were thirty-three students who were involved over a seven weeks period in practicing LCs activities. There were positive impacts on the development of language and soft skills at the end of the period of implementing LCs.

Clarke (2013) investigated the connection between literature circles and students engagement in middle years English classes. The participants of the study were 106 students who were selected from a total population of 129 year nine students. Three methods were used to collect data (surveys, interviews and field observations). The results indicated that literature circles had a positive impact on the students level of engagement.

Sagan (2015) investigated the effect of structured conversation in LCs on English language learners` oral and written skills. The study took place at a private school in a suburban neighborhood in upstate New York. The participants were third-grade classroom. Data were collected through field observations, audio recordings and writing responses. The study revealed that literature circles that focus on conversation and discussion were useful and effective for ELLs as they developed the students` oral skills, writing skills and critical thinking skills.

Sambolin \& Carroll (2015) conducted a case study of a basic English course at Puerto Rico University where LCs were used and implemented in order to develop the students`oral and written communication through understanding of a novel dealing with issues of race, class and privilege that were derived from the novel " The Boy Without a Flag" which was written by Abraham Rodriguez Jr. The results of the questionnaires, the interviews and the analysis of field notes revealed that LCs were useful and beneficial in developing the students`oral and written communication.

\section{Aim of the Study}

In the light of the problem of the study, the study aimed to develop EFL third year preparatory students' oral fluency through literature circles strategy. 


\section{Hypotheses of the Study}

The study attempted to test the following hypotheses:

1- No statistically significant difference will be found between means of scores of the control group and the experimental group on the oral fluency posttest.

2- No statistically significant difference will be found between means of scores of the control group on the pretest and posttest of oral fluency.

3- No statistically significant difference will be found between means of scores of the experimental group on the pretest and posttest of oral fluency.

\section{Significance of the Study}

While much has been said about the positive influence of literature circles in the field of EFL/ESL, a study or a research about their positive influence in developing oral fluency performance of EFL third year preparatory students is lacking in the literature. So, the study is significant for EFL students through opening up opportunities to them to develop their performance in oral fluency as a step in preparing them for their participation in the global arena and for their future careers.

It is also significant for EFL instructors at the preparatory stage as it may provide them with a framework in which they can integrate using literature circles into their set courses, attract their attention to the rationales of implementing literature circles as an effective strategy to develop their students' performance in oral fluency and assist them to get rid of the traditional strategies in developing and improving foreign language skills.

In addition, it is significant for EFL researchers and specialists as it may draw their attention to a rich area in TEFL (Literature Circles Strategy) to conduct several studies. So, the study may be helpful in leading and guiding them to the path of finding out related barriers and problems rooted from the results of the study and the possible solutions to treat and overcome such barriers and problems.

Moreover, it is significant for EFL curriculum planners and administrators. For curriculum planners, it may help them develop new and innovative strategies of teaching suitable to the students' needs and interests. For administrators, it may help them realize 
developing EFL Students' oral fluency through literature circles as an integral part of any learning process.

\section{Delimitations of the Study}

The study was delimited to:

1- EFL third year preparatory students at Gharbia Governorate.

2- The first semester of the school year 2018-2019.

3- Literature circles strategy was the strategy that used to develop EFL Students' oral fluency.

\section{Definitions of Terms}

\section{EFL Literature Circles Strategy}

It is operationally defined as small peer - led discussion groups that provide a specific framework allowing EFL third year preparatory students develop their oral fluency through real and meaningful discussions about literature in EFL and the students are involved in dealing with the same piece of literature and they come together on a regular scheduled basis to share interpretations of what they have discussed. This can be achieved through the assignment of various roles performed by students (i.e., discussion director, summarizer, vocabulary enricher, etc.) or certain tasks, which each student is given to carry out.

\section{EFL Oral Fluency}

It is operationally defined as EFL third year preparatory students` ability to express their ideas and thoughts without hesitations, repetitions, reformulations, filler words, gaps and pauses, interact effectively and respond immediately to each other when they are asked giving correct answers.

\section{Method}

\section{Participants of the Study}

Two intact classes were randomly selected from governmental preparatory schools, Gharbia Governorate during the first semester of the school year 2018-2019. One of the two classes represented the control group $(\mathrm{N}=50)$ and the other represented the experimental group $(\mathrm{N}=50)$. There was not any significant difference between experimental and control groups' mean scores on the pretest as shown in the following table: 
Table 1: The independent samples t-test for the two groups on the pretest of oral fluency

\begin{tabular}{|c|c|c|c|c|c|c|c|c|c|}
\hline \multirow{3}{*}{ Test } & \multicolumn{6}{|c|}{ Groups } & \multirow{3}{*}{$\mathrm{df}$} & \multirow{3}{*}{$\mathrm{t}$} & \multirow{3}{*}{ Sig. } \\
\hline & \multicolumn{3}{|c|}{ Experimental Group } & \multicolumn{3}{|c|}{ Control Group } & & & \\
\hline & Mean & $\begin{array}{l}\text { Std. } \\
\text { Dev. }\end{array}$ & $\mathrm{N}$. & Mean & $\begin{array}{c}\text { Std. } \\
\text { Dev. }\end{array}$ & $\mathrm{N}$. & & & \\
\hline $\begin{array}{c}\text { Oral } \\
\text { Fluency }\end{array}$ & 5.70 & 2.033 & 50 & 5.80 & 2.241 & 50 & 98 & 0.234 & No sig. $>0.01$ \\
\hline
\end{tabular}

As shown in the above table, mean scores of the two groups (experimental and control) on the pretest of oral fluency were 5.70 and 5.80 respectively. The results of the independent samples $t$-test $(t=$ $0.234, p>0.01$ ) indicate that there was not any significant difference between the two groups' mean scores on the pretest. Thus, the two groups were equal, homogeneous and enjoyed the same level of oral fluency prior to the implementation of literature circles.

Design of the Study

The design of the study is shown in the following figure:

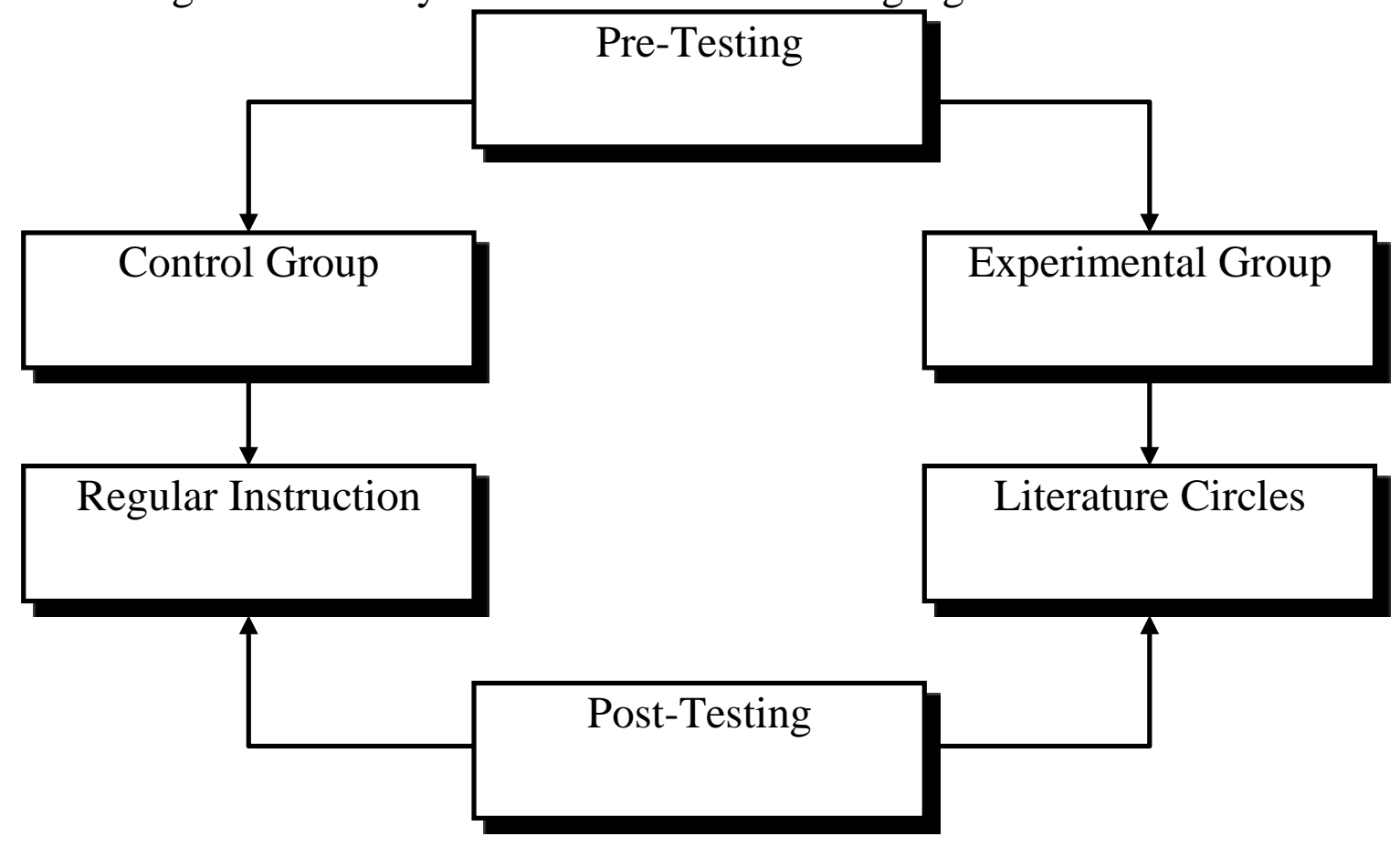

Figure (1): Design of the study (Source: Original) 
In the above figure, it is clear that the researcher used the preposttest experimental - control groups design. The experimental group students received instruction based on literature circles aiming at developing their oral fluency performance, whereas the control group students received regular instruction. The two groups were pretested before the experimentation and also posttested after it.

\section{Variables of the Study}

Independent Variable: It was the treatment used in the study (Literature Circles Strategy).

Dependent Variable: It was the students' performance in oral fluency.

\section{Instrumentation}

To measure the students`oral fluency performance before and after the treatment, an oral fluency test, prepared by the researcher, was applied as a pre-post test (see Appendix A). To be sure that instructions of the test were clear and to estimate how much time students would take in answering the test, the test was piloted to a number of EFL third year preparatory students during the first semester of the school year 2018-2019.The test was reviewed and examined by some EFL experts and jurors in the field of TEFL to determine if the test measures what it is supposed to measure. They all agreed that the test was valid in it is final from. The reliability index was estimated using KR Formula and it was found 0.85 which was statistically significant at 0.05 level.

To score and evaluate the students` oral fluency performance, a rubric was prepared to score accordingly (see Appendix B). The rubric was submitted to a number of jurors in the field of TEFL and they all agreed that the rubric was valid in its final form.

\section{Implementing LCs to the experimental group students $\square$}

The researcher reviewed the procedures and the steps that were followed by Daniels (2002) ; Furr (2004); Hsu \& Liu (2005) ; Beeghly (2005); Daniels (2006); Duff \& Maley (2007); Mark (2007); Clarke \& Holwadel (2007); Lopez (2010); Avci \&Yuksel (2011); Whittaker (2011); Shelton-Strong (2012); Calmer \&Straits (2014); Thomas (2014) \& Ragland \& Palace (2017). The researcher benefited from such studies in: (1) the selection of appropriate and relevant texts, (2) the presentation of texts, (3) the management of LCs process, (4) the formulation of groups,(5) the establishment of a schedule, (6) the variation of teacher involvement, (7) the guidance of LCs process, (8) the support of feedback to the participants, (9) the steps of conducting LCs and (10) the roles of both teacher and students. 


\section{LCs Materials}

In the light of the purpose of the study, nature of LCs, students linguistic level and texts` difficulty level, the texts were selected from the story of "Black Beauty" by Anna Sewell. A short note about the story of "Black Beauty" is provided in Appendix C.

\section{Evaluation}

Two types of evaluation were conducted in the study. The first type was formative evaluation which aimed to assess the experimental group students` gradual development in oral fluency and to provide the necessary feedback on the students performance in oral fluency after finishing each lesson. This was achieved through holding interviews with the experimental group students and using embedded tests to assess their progress during implementing LCs.

The second type was summative evaluation which aimed to investigate the influence of using LCs on the development of EFL third year preparatory students`oral fluency. This type was conducted at the end of the experimentation using the oral fluency posttest that was prepared by the researcher.

\section{Procedures of the Study} study:

The following steps were followed in conducting the

- Reviewing literature and related studies relevant to the variables of the study.

- Preparing the instruments and LCs materials and activities and then measuring their validity and reliability.

- Selecting the sample randomly from EFL third year preparatory students, and dividing the selected sample randomly into two groups (experimental and control).

- Applying pre-testing to the whole sample of the study.

- Implementing the experimentation.

- Applying post-testing to the whole sample of the study.

- Analyzing the results statistically using SPSS.

- Discussing and interpreting the collected data.

- Providing implications, recommendations, suggestions for future research and conclusions. 


\section{Results of the Study}

Results Related to the First Hypothesis of the Study

"No statistically significant difference will be found between means of scores of the control group and the experimental group on the oral fluency posttest"

In order to verify the validity of this hypothesis, the independent samples t-test was used and the results are shown in the following table:

Table 2: The independent samples t-test for the two groups on the posttest of oral fluency

\begin{tabular}{|c|c|c|c|c|c|c|c|c|c|}
\hline \multirow{3}{*}{ Test } & \multicolumn{6}{|c|}{ Groups } & \multirow{3}{*}{ df } & \multirow{3}{*}{$\mathrm{t}$} & \multirow{3}{*}{ Sig. } \\
\hline & \multicolumn{3}{|c|}{ Experimental Group } & \multicolumn{3}{|c|}{ Control Group } & & & \\
\hline & Mean & $\begin{array}{l}\text { Std. } \\
\text { Dev. }\end{array}$ & N. & Mean & $\begin{array}{l}\text { Std. } \\
\text { Dev. }\end{array}$ & $\mathrm{N}$. & & & \\
\hline $\begin{array}{c}\text { Oral } \\
\text { Fluency }\end{array}$ & 11.52 & 1.418 & 50 & 8.28 & 1.830 & 50 & 98 & 9.897 & Sig. $<0.01$ \\
\hline
\end{tabular}

It can be concluded that there is a statistically significant difference between means of scores of the experimental group $(\mathrm{M}=11.52, \mathrm{SD}=1.418, \mathrm{df}=98)$ and that of the control group $(\mathrm{M}=8.28$, $\mathrm{SD}=1.830, \mathrm{df}=98)$ on the posttest of oral fluency $(\mathrm{t}=9.897, \mathrm{p}<0.01)$, in favor of the experimental group. Thus, the first null hypothesis is rejected as the difference between the two groups is statistically significant at 0.01 . So, the corresponding alternative hypothesis is accepted. The results are visualized graphically in the following figure:

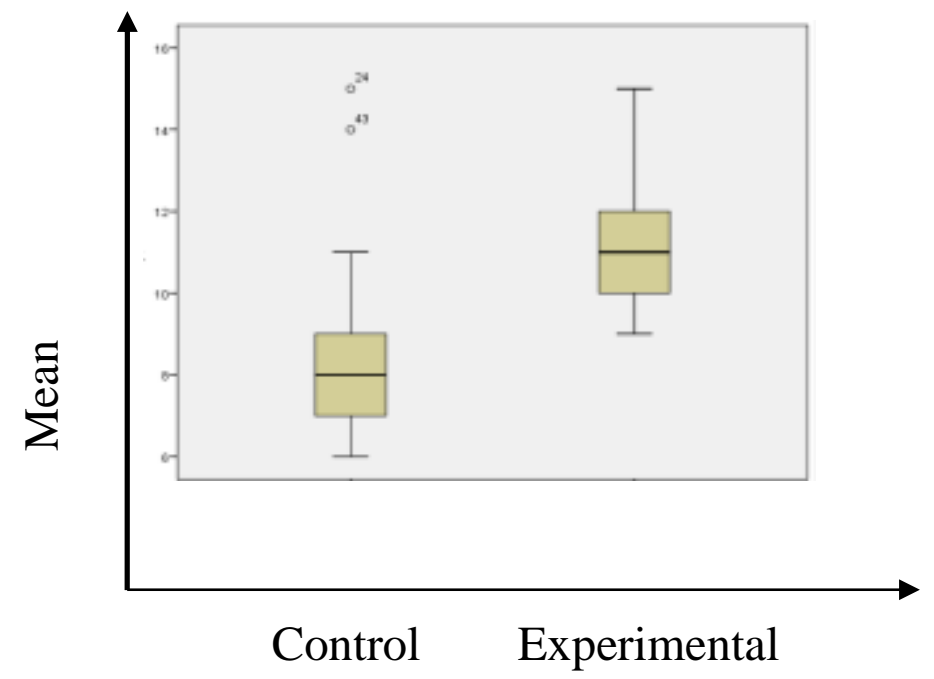

Figure (2): Mean scores for the two groups on the posttest of oral fluency 


\section{Results Related to the Second Hypothesis of the Study}

"No statistically significant difference will be found between means of scores of the control group on the pretest and posttest of oral fluency"

In order to verify the validity of this hypothesis, the paired samples t-test was used to compare the control group's mean scores on the pretest and posttest of oral fluency. The result of the comparison is shown in the following table:

Table 3: The paired samples t-test for the control group on the pretest and posttest of oral fluency

\begin{tabular}{|c|c|c|c|c|c|c|c|c|c|}
\hline \multirow{3}{*}{ Group } & \multicolumn{6}{|c|}{ Oral Fluency Test } & \multirow{3}{*}{ df } & \multirow{3}{*}{$\mathrm{t}$} & \multirow{3}{*}{ Sig. } \\
\hline & \multicolumn{3}{|c|}{ pretest } & \multicolumn{3}{|c|}{ Posttest } & & & \\
\hline & Mean & $\begin{array}{l}\text { Std. } \\
\text { Dev. }\end{array}$ & N. & Mean & $\begin{array}{l}\text { Std. } \\
\text { Dev. }\end{array}$ & N. & & & \\
\hline $\begin{array}{l}\text { Control } \\
\text { Group }\end{array}$ & 5.80 & 2.241 & 50 & 8.28 & 1.830 & 50 & 49 & 15.287 & Sig. $<0.01$ \\
\hline
\end{tabular}

As shown in Table (3), there is a statistically significant difference in means of scores of the control group on the pretest $(\mathrm{M}=5.80, \mathrm{SD}=2.241, \mathrm{df}=49)$ and posttest $(\mathrm{M}=8.28, \mathrm{SD}=1.830, \mathrm{df}=49)$ of oral fluency, in favor of the posttest $(\mathrm{t}=15.287, \mathrm{df}=49, \mathrm{p}<0.01)$. Accordingly, the second null hypothesis is rejected as the difference is statistically significant at 0.01 and the corresponding alternative hypothesis is accepted. The results are visualized graphically in the following figure:

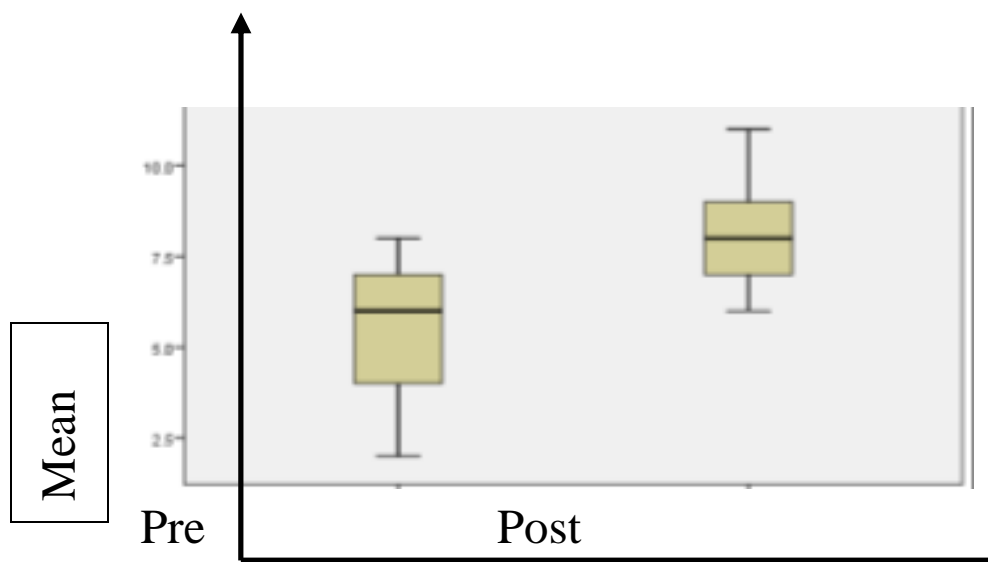

Figure (3): Mean scores of the pretest and posttest of oral fluency for the control group 


\section{Results Related to the Third Hypothesis of the Study}

"No statistically significant difference will be found between means of scores of the experimental group on the pretest and posttest of oral fluency"

In order to test the third hypothesis, the paired samples t-test was used to compare the experimental group's mean scores on the pretest and posttest of oral fluency. The result of the comparison is shown in the following table.

Table 4: The paired samples t-test for the experimental group on the pretest and posttest of oral fluency

\begin{tabular}{|c|c|c|c|c|c|c|c|c|c|}
\hline \multirow{3}{*}{ Group } & \multicolumn{6}{|c|}{ Oral Fluency Test } & \multirow{3}{*}{ df } & \multirow{3}{*}{$\mathrm{t}$} & \multirow{3}{*}{ Sig. } \\
\hline & \multicolumn{3}{|c|}{ pretest } & \multicolumn{3}{|c|}{ Posttest } & & & \\
\hline & Mean & $\begin{array}{l}\text { Std. } \\
\text { Dev. }\end{array}$ & $\mathrm{N}$. & Mean & $\begin{array}{l}\text { Std. } \\
\text { Dev. }\end{array}$ & N. & & & \\
\hline $\begin{array}{l}\text { Experimental } \\
\text { Group }\end{array}$ & 5.70 & 2.033 & 50 & 11.52 & 1.418 & 50 & 49 & 31.548 & Sig. $<0.01$ \\
\hline
\end{tabular}

Table (4) shows that there is a statistically significant difference, in favor of the posttest $(t=31.548, d f=49, p<0.01)$. This result shows that the experimental group students performed better on oral fluency posttest than oral fluency pretest. Accordingly, the third hypothesis of the study is rejected as the difference is statistically significant at 0.01 , in turn, the corresponding alternative hypothesis is accepted. The results are visualized graphically in the following figure:

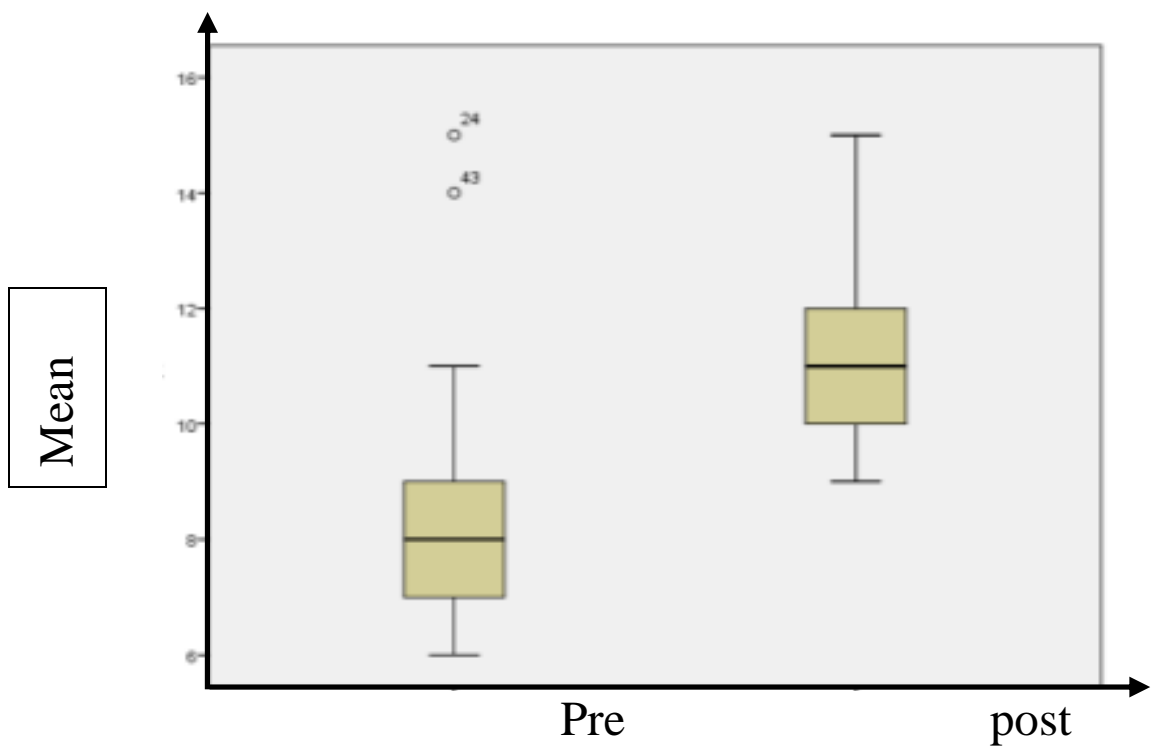

Figure (4): Mean scores of the pretest and posttest of oral fluency for the experimental group 


\section{Discussion}

The results of the study indicated that there was improvement in the experimental group students` level of oral fluency and the students of the experimental group outperformed and surpassed the students of the control group on the oral fluency posttest. This means that using literature circles strategy was more useful and beneficial than that used by the control group students in developing EFL third year preparatory students` oral fluency as the statistical difference was in favor of the experimental group students.

This result may be due to that literature circles strategy gave the students several opportunities to open up discussions in the classroom where they felt comfortable, relaxed, motivated and interested, which in turn, helped them express their ideas and thoughts freely without requiring gaps, hesitations and pauses. The students felt previously uncomfortable before implementing LCs as most of them hesitated and took much time when speaking EFL. In LCs, they had several opportunities that made them participate actively and speak fluently without pauses and hesitations.

This result may also be due to the chosen texts to be discussed and negotiated in LCs. The texts selected from the story of "Black Beauty" were relevant, appropriate and interesting that provided students of the experimental group with issues and questions that most of them expressed that such issues and questions were motivating and useful for developing their levels of oral fluency. This factor, the chosen texts, helped students generate many comments, questions, discussions and suggestions, in turn, enabled them answer the questions immediately and fluently without filler words and reformulations. So, selecting materials that connected to the students' backgrounds enabled them be engaged in using EFL in meaningful and purposeful way and promote community building as students had the opportunity to share and discuss ideas with other students of their groups.

Another explanation may be that literature circles strategy were beneficial and useful for the experimental group students in providing them many opportunities for social interaction and communication about issues and themes important to them. The students in LCs were engaged in meaningful oral discussions that enabled them practice and develop their oral fluency. 
In addition, LCs helped the students to be actively involved in oral discussions, transmitted the information in active ways, provided enough space for them to comment orally, justified and mirrored themselves, engaged them in complex textual analysis, gave them a clear purpose for discussing literature, received useful feedback from their peers and from their teacher on their performance and provided them with appropriate scaffolding through role, peer and teacher support, in turn, enabled them develop and enhance their oral fluency. Moreover, the results of the study may be due to the level and the amount of autonomy and flexibility given to the experimental group students that were obvious and clear through the roles performed by them. Each one performed and functioned several roles (i.e., group discussion leader, summarizer, connector, word master, passage person, investigator, travel tracer, etc.). These roles were rotated with each discussion so that all students had the opportunity to perform and function all these roles. These roles helped the experimental group students not only to be autonomous and active in their EFL classroom but also gave them an opportunity to work on their own to formulate their own questions, discuss and exchange thoughts and ideas, negotiate meaning, engage in collaborative scaffolding within a small group of peers and practice real communication about themes and issues important to them. This, in turn, developed and enhanced the students` level of oral fluency.

An important explanation of the results of the study may be due to the small sizes of the groups in LCs that were suitable in terms of class management and this helped the students of the experimental group be more inclined to ask questions, be more attentive to each other, exchange ideas and information fluently and transform students from passive, rather shy and reticent, into active participants in order to support their arguments and viewpoints .This created and initiated opportunities wherein the experimental group students were led to develop their oral fluency level in EFL through the discussion circle, where natural and authentic interaction occurred.

A further explanation may be due to that literature circles turned passive students into active ones who produced thoughts and ideas, made students conscious that they were able to contribute to a part of their oral fluency development, helped students learn from each other, instead of being dependent on their EFL teacher, involved students in 
meaningful negotiations that helped them overcome classroom conflicts, reduced the students` apprehension from speaking EFL and created a secure environment that assisted them to communicate orally in EFL and this logically resulted in developing their level of oral fluency.

From the field observations that were noticed throughout the implementation of LCs that most students of the experimental group were very enthusiastic about oral discussions in LCs, felt more secure and comfortable admitting their confusions about texts, formulated their answers and responses more thoughtfully and were motivated to speak EFL fluently. So, to be sure that the experimental group students were motivated and enthusiastic about their participation in LCs, they were interviewed orally several times by the researcher. In the interviews, they were asked about the advantages and the benefits of LCs for them and they were asked to answer orally.

Examples of the most common answers that were received from the students of the experimental group in the interviews were:" They were fun and useful", "They helped me to ask questions", "We helped each other with difficult words in LCs", "We worked in a group and we communicated in English in LCs ", "They helped me to understand the events of the story", "They were useful because they made me speak fluently", "We enjoyed them" and "They helped me express my ideas and thoughts freely and clearly".

The results of the study are in agreement with the the results of the studies conducted by (Daniels ,2002 ; Furr ,2004; Reppert ,2004; McElvain ,2005; Hsu \& Liu ,2005 , Beeghly ,2005, Lin ,2006; Daniels ,2006, Duff \& Maley ,2007; Mark ,2007; Clarke \& Holwadel ,2007; Dasilva Iddings, Risko \& Ramplulla ,2009; Anderson ,2009; Lopez ,2010; Avci \&Yuksel ,2011, Whittaker ,2011; Shelton-Strong ,2012; Azmi ,2013; Clarke ,2013; Calmer \&Straits ,2014; Thomas ,2014 ;Sagan ,2015; Sambolin \& Carroll ,2015 \& Ragland \& Palace ,2017).

\section{Implications}

Teachers may face some problems in managing and organizing LCs, so it is significant for them to have training on the procedures, organization, implementation and management of LCs. Schools and supervision can do this through holding training courses or workshops for EFL teachers. 
In order to implement LCs correctly, EFL teachers should organize mini lessons of LCs into their classrooms, adapting some basic concepts of them. The aim of such mini lessons is to provide students with previous knowledge of what LCs are, which in turn, make them easier.

The small size of groups in LCs is an important factor for successful LCs because students feel comfortable and relaxed in small groups. So, the students enjoy the relaxation and the safety of small group setting in which they can better negotiate meaning, share ideas, exchange thoughts and seek clarification.

In LCs, the students exactly know what was expected of them from the very beginning of the intervention as the students have certain and determined roles to perform according to their choices (i.e., summarizer, vocabulary enricher, etc.).So,

using LCs is an exciting strategy for developing EFL students`oral fluency in a natural way.

In addition, a number of social skills could be enhanced when monitoring a discussion group (i.e., taking turns, asking questions, leaning forward, avoiding dominating, avoiding interrupting, showing respect for other's ideas, helping others find evidence, etc.). Consequently, it is useful for EFL teachers to adopt such strategy (LCs) into their instruction.

\section{Recommendations}

Based on the study results, the following recommendations should be considered:

1- Faculties of education and supervisors should encourage and train in- service EFL teachers on how to implement LCs in developing and improving oral fluency.

2- Curriculum designers should incorporate and include LCs in EFL curricula at the preparatory stage.

3- EFL teachers should be provided with various references and books about implementing and using LCs in developing EFL students` oral fluency.

4- Training courses and workshops for EFL teachers and EFL supervisors should be held about procedures and steps of implementing LCs. 
5- EFL supervisors should follow-up their EFL teachers to be sure that their EFL teachers implement LCs correctly and provide guidance when necessary.

6- EFL students should be given enough opportunities to express their thoughts, viewpoints and ideas freely.

7- Enough time should be allocated for EFL students to develop their oral fluency as much as possible as it takes much time.

\section{Suggestions for Future Research}

There are some avenues for future research that have arisen as a result of the study as follows:

1- A comparative study could be conducted between traditional literature circles and online literatures circles and investigate the impact of each one on the students development of oral fluency.

2- Conducting analytical and qualitative studies in the area of incorporating LCs to develop EFL students`oral fluency.

3- Several studies can be conducted using LCs at other educational stages.

4- Exploring the impact of LCs on the development of other foreign language skills; namely listening; reading and writing.

5- Investigating the effectiveness of LCs in developing EFL students`oral accuracy.

6- Exploring the effect of LCs in increasing the students`attitudes towards EFL.

7- Investigating the effect of LCs on the development of the students`cultural awareness.

\section{Bonclusions}

The results of the study indicated the positive influence of implementing literature circles strategy on the development of EFL third year preparatory students` oral fluency, in favor of the students of the experimental group compared to the students of the control group who received regular instruction. Such results could be significant for EFL students, EFL teachers, EFL researchers and EFL curriculum planners and administrators. 


\section{References}

Alis, S. (1994). The reader-response approach: An alternative for teaching literature in a second language. Journal of Reading, 37, 288-296.

Anderson, P. L., \& Corbett, L. (2008). Literature circles for students with learning disabilities. Intervention in School and Clinic, 44, 25-33.

Anderson, P.L. (2009). Engaging students in online literature circle conversation. Conference of the International Journal of Arts and Sciences, 1(17), 38-42.

Anderson,P.(2009).Engaging students in online literature conversations. Conference of the International Journal of Arts and Sciences, 1(17), 38-42.

Avci, S., \& Yuksel, A. (2011). Cognitive and affective contributions of the literature circles method on the acquisition of reading habits and comprehension skills in primary level students. Education Sciences Theory \& Practice, 11(3), 1295-1300.

Azmi, M. (2013). Developing soft skills using literature circles. The Malaysian Online Journal of Educational Science, 1(2), 8-16.

Beeghly, D.G. (2005). It's about time: Using electronic literature discussion groups with adult learners. Journal of Adolescent \& Adult Literacy, 49, 12-21.

Blanton, W., Wood, K., \& Taylor, D. (2007). Rethinking middle school reading instruction: A basic literacy activity. Reading Psychology, 28(1), 75-95.

Blum, T., Lipsett, L, \& Yocom, D. (2002) Literature circles: A tool for self- determination in one middle school inclusive classroom.Remedial and Special Education, 23 (2), 99108. 
Brown, B. A. (2002). Literature circles in action in the middle school classroom. Georgia College and State University. ERIC Document Reproduction Service No.ED478458.

Burner, K. J. (2007). The effects of reflective and reflexive writing prompts on students' self-regulation and academic performance. Unpublished doctoral thesis, Florida State University, Tallahassee.

Calmer, J., \& Straits, W. (2014). Reading to understand anatomy. The American Biology Teacher, 76(9), 622-625.

Carrison, C. (2005).From silence to a whisper to active participation: Using literature circles with ELL students. Reading Horizons, 46(2), 93-113.

Carrison, C., Ernst-Slavit, G.,\& Spiesman-Laughlin, J. (2009). Creating opportunities for "grand conversations" among ELLs with literature circles. In J. Coppola \& E.

Casey, H. K. (December 2008/January 2009). Engaging the disengaged: Using learning clubs to motivate struggling adolescent readers and writers. Journal of Adolescent \& Adult Literacy, 52(4), 284-294.

Certo, J., Moxley, K., Reffitt, K., \& Miller, J. A. (2010). I learned how to talk about a book: Children's perceptions of literature circles across grade and ability levels. Literacy Research \& Instruction, 49, 243-263.

Chase, P., \& Pheifer, D. (2002).Summary of literature circles. Retrieved July5,2017,from www.chasepheifer.com/pdf/LitCrcResearch.pdf.

Chi, Q. (2008). Study of group discussion in EFL classroom teaching. Sino-US English Teaching, 5 (2), 57-61. 
Clarke, L. (2013).The impact of literature circles on student's engagement in middle years English. Unpublished master thesis, Melbourne Graduate School of Education, The University of Melbourne.

Daniels, H. (2002). Literature circles: Voice and choice in book clubs and reading groups( 2 nd ed.). Portland, ME: Stenhouse.

Daniels, H. (2006). What's the next big thing with literature circles?Voices from the Middle, 13(4), 10-15.

Daniels, H., \& Steineke , N. (2004). Mini-lessons for literature circles. Portsmouth, NH: Heinemann.

Dasilva Iddings, A., Risko, V., \& Ramplulla, M. (2009). When you don't speak their language: Guiding English-language learner through conversations about text. The Reading Teacher, 63(1), 52-61.

Day, C. (2004). Reading and responding in literature circles. ERIC Document Reproduction Service No. 480271.

Day, D., \& Kroon, S. (2010). Online literature circles rock!: Organizing online literature circles in a middle school classroom. Middle School Journal, 42(2), 18-28.

Day, J., Spiegel, D., McLellan, J., \& Brown, V. (2002). Moving forward with literature circles. New York, NY: Scholastic.

De Jong, N.H., Groenhout, R., Hulstijn, J.H., \& Schoonen, R.(2015). Second language fluency: Speaking styles or proficiency? Correcting measures of second language fluency for first language behavior. Applied psycholinguistics, 36, 223243.

Dotan-Eliaz , O. (2008). Working in multilingual settings. Retrieved January 15,2017,fromhttp://gradworks.umi.com/32/96/3296961.html. 
Duff, A., \& A. Maley. (2007). Literature (2 nd ed.). Oxford: Oxford University Press.

Echevarria, J., M. Vogt, \& D. J. Short. (2008). Making content comprehensible for English learners: The SIOP Model( 3rd ed.). Boston: Allyn and Bacon.

Egbert, J. (2007). Asking useful questions: Goals, engagement, and differentiation in technology-enhanced language learning. Teaching English with Technology, 7 (1).Retrieved January 20,2017,from www.tewtjournal.org/ pastissues2007.htm.

Egbert,J.,\&Elhess,M.(2015).Literature circles as support for language development. English Teaching forum. Retrieved May 10, 2017,from americanenglish.state.gov./englishteaching-forum.

Egle, C. H. (2002). Literature circles. Unpublished master thesis, Winona State University, Minnesota.

Ellis, R. (2009). The differential effects of three types of task planning on the fluency, complexity, and accuracy in L2 oral production. Applied Linguistics, 30(4), 474-509.

Flynt, E.S., \& Brozo, W. G. (2009). It's all about the teacher. The Reading Teacher, 62(6), 536-538.

Furr, M. (2004). Literature circles for the EFL classroom. Proceedings of the 2003 TESOL Arabia Conference. TESOL Arabia: Dubai, UAE.

Furr, M. (2005).Welcome to literature circles. Retrieved May 5, 2017, from www.eflliteraturecircles.com.

Furr,M.(2004). Literature circles for the EFL classroom. Retrieved October 20 , 2017,from http://www.eflliteraturecircles.com/ litcirclesforEFL. 
Goh, C., \& Burns, A. (2012). Teaching speaking: A holistic approach. New York: Cambridge University Press.

Haddon, W. (2003). The practice of English Literature. Longman.

Hempel, K. (2005). Literature circles. Retrieved May 10, 2017, from ccb.lis.illinois.edu/.../hempel/LiteratureCircles.htm.

Hill, B., Noe, K., \& King, J. (2003). Literature circles in the middle school: One teacher's journey. Norwood, MA: Christopher-Gordon Publishers.

Housen, A., \&Kuiken, F. (2009). Complexity, accuracy, and fluency in second language acquisition. Applied Linguistics, 30(4), 461-473.

Hsu, J-Y. (2003). Reading together: Student teacher meet in literature circles. The Proceedings of the 2003 National Conference on English Teaching and Learning (pp.1-9). Huwei Institute of Technology, Huwei, Taiwan.

Hsu, J-Y. (2004). Reading without teachers: Literature circles in an EFL classroom. The Proceedings of 2004 Cross-Strait Conference on English Education (pp. 401-421). National Chiayi University, Chiayi, Taiwan.

Hsu, J-Y\& Liu, S-Y. (2005). Faulker's Emily revives: Experimenting literature circles with Taiwanese college students. Paper presented at the 22nd International Conference on English Teaching and Learning in the Republic of China. National Taiwan Normal University, Taipei, Taiwan.

Huang, H. (2008).Implementing literature circles in an EFL reading class at a Technological University. Unpublished master thesis, National Kaohsiung University, Taiwan.

Johnson, G.N. (2001). Literature discussion in the elementary school classroom: Developing cultural understanding. Multicultural Education, 8(1), 33-36. 
Ketch, A. (2005). Conversation: The comprehension connection. The Reading Teacher, 59 (1) 8-13.

Kim, M. (2004). Literature discussions in adult L2 learning. Language and Education, 18(2), 145-166.

Koponen, M., \& Riggenback, H. (2000). Overview: Varying perspectives on fluency. In H.Riggenback (Eds.), Perspectives on fluency (5-24).Ann Arbor, MI: The University of Michigan Press.

Larson, L. C. (2008). Electronic reading workshop: Beyond books with new literacies and instructional technologies. Journal of Adolescent and Adult Literacy, 52 (2) 121131.

Lennon, P. (2000). The lexical element in spoken second language fluency. In H.Riggenback (Eds.), Perspectives on fluency (pp.25-42).Ann Arbor, MI: The University of Michigan Press.

Levy, R. (2011). Literature circles go to college. Journal of Basic Writing, 30(2), 53-83.

Lin, C. (2004). Literature circles. Teacher Librarian, 31(3), 23-25.

Lin, S-J. (2006). The effects of literature circles on EFL learning of children in a bilingual class. Unpublished master thesis, Kaohsiung Normal University, Taiwan.

Lopez, J. (2010). Teaching and learning: Literature circles. Retrieved May

20,2017,fromhttp://www.litsite.org/index.cfm?section'1/4T eachingandLearning\&page $1 / 4$ ReadingWorkbooks\&cat $1 / 4 \mathrm{M}$ iddleSchool\&viewpost $1 / 42 \&$ ContentId $1 / 41015$.

Maloch, B. (2004). On the road to literature discussion groups: Teacher scaffolding during preparatory experiences. Reading Research and Instruction, 44(2), 1-20. 
Mark, P. L. (2007). Building a community of EFL readers: Setting up literature circles in a Japanese university in K. BradfordWatts (Eds.). JALT 2006 Conference Proceedings. Tokyo: JALT .

McElvain, C. (2005). Transactional literature circles and the reading comprehension of at-risk English learners in the mainstream classroom. Unpublished doctoral thesis, University of San Francisco.

McMahon, S. I. (1997). Book clubs: Contexts for students to lead their discussions. In I. S. McMahon; T. E. Raphael; V. J. Goatley, \& L. S. Pardo (Eds.), The book club connection, (pp. 89-106). NewYork: Teachers College, Columbia University.

McNair, T., \& Nations, S. (2000). Final reflections: How Fairview became a school where literature circles could thrive. Primary Voices K-6, 9(1), 34-38.

Mora,C.J., \& Valls-Ferrer,M. (2012). Oral fluency, accuracy, and complexity in formal instruction and study aboard learning contexts. TESOL Quarterly, 46(4), 610-641.

Nagy, W., \& D. Townsend. (2012). Words as tools: Learning academic vocabulary as language acquisition. Reading Research Quarterly, 47 (1), 91-108.

Nation, I.S.P., \& Newton, J. (2009). Teaching ESL/EFL listening and speaking. New York: Routledge.

Primas (Eds.), One classroom, many learners: Best literacy practices for today`s multilingual classrooms (pp.91-117). International Reading Association.

Ragland, J., \& Palace, C. (2017). Literature circles for adolescent developmental readers. English Journal, 106(6), 35-40.

Reid, S. (2002). Book Bridge for ESL students: Using young adult literature and children literature to teach ESL. Lanham, MD: Scarecrow Press. 
Reppert, K.R. (2004).Literature and the development of oral fluency: A study using poetry and children's literature in adult ESL instruction. Retrieved January 10, 2017, from libdr.iastate.edu/ rtd.

Sagan, O. (2015). The benefits of structured conversation in a literacy circle with English language learners. Retrieved January 20 , 2017 , from http://digitalcommons.brockport.edu/ehd theses.

Sambolin, A.N., \& Carroll, K.S. (2015). Using literature circles in the ESL college classroom: A lesson from Puerto Rico. Colomb. Appl. Linguist.J., 17(2), 193-206.

Sawyer, R. K. (2006). The Cambridge handbook of the learning sciences (Eds.). Cambridge: Cambridge University Press.

Shelton-Strong,S.J.(2012).Literature circles inELT.ELTJournal,66(2),214-223.

Stein, D., \&Bede, P.L. (2004). Bridging the gap between fiction and nonfiction in the literature circle setting. The Reading Teacher, 57(6), 510-518.

Thomas, A. F. (2014). An action research study involving motivating middle school students learning through online literature circles. Journal of Ethnographic \&Qualitative Research, 9, 44-54.

Whittaker, C. (2011). Integrating literature circles into a co-taught inclusive classroom. Intervention in School and Clinic, 47(4), 214-223.

Williams, S. M. (2009). The impact of collaborative, scaffolded learning in K-12 schools: A meta-analysis. Los Angeles: Metiri Group.

Yedlin, J. (2004). Teacher talk: Enabling ELLs to grab on and climb high. Perspectives. Retrieved October 20, 2017, from http://www.mec.edu/mascd/docs/yedlin.htm. 


\section{Appendix A}

\section{Oral Fluency Test}

A) Answer the following questions orally:

1 - Tell me a lesson you learned from the story.

2- What does a horse need after a long journey?

3- Mention the similarities between John Manly and Joe Green.

4- What do you think would happen if Black Beauty crossed the bridge?

5- How was John Manly a kind helper?

6- Do you think that we should learn from our mistakes? why ?

7- Gordon was happy when they went out of the wood after the journey.Discuss.

8- If you have a horse who bites and kicks, what will you do with it?

9- Do you think Squire Gordon was grateful to Black Beauty?why?why not?

10- In your opinion, who is more wiser: Black Beauty or Gordon about crossing the bridge? why?

B) Say three sentences about each picture of the following:

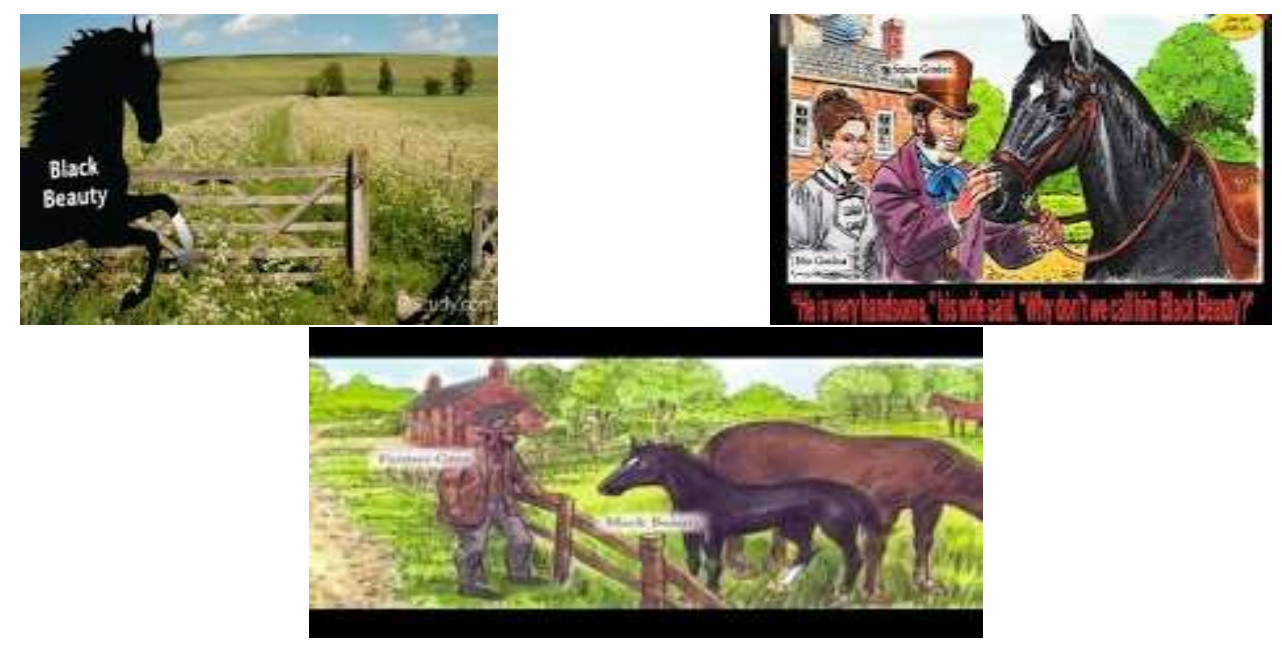

(1)

(2)

(3) 


\section{Appendix B}

Oral Fluency Scoring Rubric

\begin{tabular}{|c|c|c|c|c|}
\hline $\begin{array}{c}\text { Student's } \\
\text { Performance }\end{array}$ & Poor(1) & Fair(2) & Good(3) & Excellent(4) \\
\hline $\begin{array}{c}\text { Student speaks } \\
\text { with pauses and } \\
\text { gaps. }\end{array}$ & $\begin{array}{c}\text { Student } \\
\text { expresses } \\
\text { his/her ideas } \\
\text { and thoughts } \\
\text { with frequent } \\
\text { pauses and } \\
\text { gaps. }\end{array}$ & $\begin{array}{c}\text { Student } \\
\text { expresses } \\
\text { his/her ideas } \\
\text { and thoughts } \\
\text { using pauses } \\
\text { and gaps when } \\
\text { necessary. }\end{array}$ & $\begin{array}{c}\text { Student } \\
\text { expresses } \\
\text { his/her ideas } \\
\text { and thoughts } \\
\text { requiring very } \\
\text { little pauses and } \\
\text { gaps. }\end{array}$ & $\begin{array}{c}\text { Student } \\
\text { expresses } \\
\text { his/her ideas } \\
\text { and thoughts } \\
\text { without } \\
\text { requiring gaps } \\
\text { and pauses. }\end{array}$ \\
\hline $\begin{array}{l}\text { Student takes a } \\
\text { considerable } \\
\text { time to express } \\
\text { his/her thoughts } \\
\text { and ideas. }\end{array}$ & $\begin{array}{l}\text { The } \\
\text { information is } \\
\text { very limited. }\end{array}$ & $\begin{array}{c}\text { Late in } \\
\text { expressing } \\
\text { his/her thoughts } \\
\text { and ideas. }\end{array}$ & $\begin{array}{c}\text { Takes the } \\
\text { advantage of } \\
\text { time in } \\
\text { expressing } \\
\text { his/her thoughts } \\
\text { and ideas (more } \\
\text { than one idea). }\end{array}$ & $\begin{array}{l}\text { Take time in } \\
\text { expressing } \\
\text { many thoughts } \\
\text { and ideas (as } \\
\text { much as he/she } \\
\text { can). }\end{array}$ \\
\hline $\begin{array}{l}\text { Student can } \\
\text { answer } \\
\text { immediately } \\
\text { when he/she } \\
\text { asked. }\end{array}$ & $\begin{array}{l}\text { Takes much } \\
\text { time to think } \\
\text { and then } \\
\text { answers. }\end{array}$ & $\begin{array}{c}\text { Takes } \\
\text { considerable } \\
\text { time to think } \\
\text { and then } \\
\text { answers. }\end{array}$ & $\begin{array}{l}\text { Takes little time } \\
\text { to think and } \\
\text { then answers. }\end{array}$ & $\begin{array}{c}\text { Answers } \\
\text { immediately. }\end{array}$ \\
\hline $\begin{array}{l}\text { Student`s } \\
\text { answers are } \\
\text { appropriate to } \\
\text { the questions. }\end{array}$ & $\begin{array}{l}\text { Answers are } \\
\text { inaccurate in } \\
\text { relation to the } \\
\text { questions. }\end{array}$ & $\begin{array}{l}\text { Most answers } \\
\text { are accurate in } \\
\text { relation to the } \\
\text { questions } \\
\text { (requires } \\
\text { repetitions). }\end{array}$ & $\begin{array}{l}\text { Few errors are } \\
\text { existed in } \\
\text { Answers in } \\
\text { relation to the } \\
\text { questions. }\end{array}$ & $\begin{array}{l}\text { Answers are } \\
\text { accurate to the } \\
\text { questions. }\end{array}$ \\
\hline $\begin{array}{l}\text { Student shares } \\
\text { information and } \\
\text { interacts with } \\
\text { his/her group. }\end{array}$ & $\begin{array}{l}\text { Shares very } \\
\text { little } \\
\text { information } \\
\text { with his/her } \\
\text { group. }\end{array}$ & $\begin{array}{l}\text { Shares the } \\
\text { required } \\
\text { information } \\
\text { with his/her } \\
\text { group with } \\
\text { correction when } \\
\text { necessary. }\end{array}$ & $\begin{array}{l}\text { Shares } \\
\text { information } \\
\text { with his/her } \\
\text { group with } \\
\text { correction. }\end{array}$ & $\begin{array}{c}\text { Shares } \\
\text { information } \\
\text { with his/her } \\
\text { group with } \\
\text { correction as } \\
\text { many times as } \\
\text { possible. }\end{array}$ \\
\hline
\end{tabular}




\section{Appendix C}

\section{A Short Note about the Story "Black Beauty"}

The Writer: Anna Sewell (1820-1878)

She was born in England in 1820. Her legs were damaged when she was a child because of an accident. From this time, she used to drive a carriage with a horse as she couldn't walk. She loved horses very much that helped her travel around. She decided to write stories like her mother. She wanted people to understand that looking after horses was important and as a result she wrote "Black Beauty" in 1877.

\section{Main Theme of the Story}

Black Beauty`s main theme is looking after animals, in general and horses, in particular in an attempt to help stop the abuses against them.

\section{Main Characters of the Story "Black Beauty"}

- Farmer Grey: Black Beauty`s first owner.

- Squire Gordon: The first owner who Black Beauty worked for.

- Mrs. Gordon: Squire Gordon`s wife.

- John Manly: A kind man who was Squire Gordon's helper.

- Joe Green: A boy who helped John Manly.

- Earl Smythe: A rich man who bought Black Beauty from Squire Gordon.

- Lady Smythe: Earl Smythe`s wife.

- York: Earl Smythe`s helper.

\section{Horses of the story "Black Beauty"}

Black Beauty: A black horse who told the story (a male horse).

Merrylegs: A short, fat horse who carried the children at Squire Gordon (a male horse).

Ginger: Black Beauty`s friend who had a difficult past (a female horse). 